\title{
PENERAPAN PERANCANGAN PADA PENATAAN BANGUNAN DAN LINGKUNGAN KERAJINAN KERAMIK DI KELURAHAN DINOYO, KECAMATAN LOWOKWARU KOTA MALANG
}

\author{
Adhi Widyarthara \\ Dosen Prodi Arsitektur, Fak. Teknik Sipil dan Perencanaan, ITN Malang \\ e-mail: adhiwidyarthara@lecturer.itn.ac.id \\ Hamka \\ Dosen Prodi Arsitektur, Fak. Teknik Sipil dan Perencanaan, ITN Malang \\ e-mail: hamka07@lecturer.itn.ac.id \\ Suryo Tri Harjanto \\ Dosen Prodi Arsitektur, Fak. Teknik Sipil dan Perencanaan, ITN Malang \\ e-mail: totosuryosaja@gmail.com
}

\begin{abstract}
ABSTRAK
Keberadaan kawasan pengrajin keramik merupakan potensi sebagai destinasi wisata untuk kawasan Kota Malang dengan karakteristik perilaku dalam memproduksi benda-benda guna memenuhi kebutuhan masyarakat. Citra kawasan pengrajin keramik yang mulai meredup karena keterbatasan fasilitas dalam mengekspose budaya yakni memproses pembuatan keramik hingga memamerkan produk keramik maupun menjualnya. Sejalan dengan keinginan penghuni kawasan untuk menjadikan Kampoeng Wisata Keramik Dinoyo, membutuhkan peranan mereka yang terlibat agar dapat mencapai apa yang dicita-citakannya. Peran Pemerintah sangat penting dalam mengendalikan fungsi kawasan karena sebagai pemegang regulasi dalam penataan bangunan maupun lingkungan yang berkelanjutan. Masyarakat dapat menyediakan beberapa kebutuhan yang dapat menjadikan pemilik bangunan, pekerja maupun pengunjung merasa nyaman dalam berinteraksi dalam kawasan. Salah satu program yang diusulkan dapat meningkatkan kualitas lingkungan serta meningkatkan citra kawasan berdasarkan peran Pemerintah dan masyarakat adalah pemberlakuan garis sempadan bangunan pada kawasan pengrajin keramik; pembukaan ruang tersebut dapat difungsikan sebagai ruang transisi antara teritori publik dan teritori primer sehingga akan mengintegrasikan kultur pengunjung dan kultur pengrajin keramik. Apabila semuanya dapat terwujud, diharapkan kawasan ini akan memiliki nilai sosial, nilai ilmiah serta nilai komersial yang bermanfaat bagi masyarakat dan lingkungan serta berkelanjutan dalam mewujudkan kemakmuran bagi penghuninya
\end{abstract}

Kata kunci : penataan bangunan, lingkungan, berkelanjutan. 


\begin{abstract}
The existence of ceramic craftsmen is a potential as a tourist destination for the Malang City region with behavioral characteristics in producing objects to meet people's needs. The image of the area of ceramic craftsmen that began to fade because of the limited facilities in exposing the culture of processing ceramics to exhibiting ceramic products and selling them. In line with the wishes of the inhabitants of the area to make the Dinoyo Ceramics Tourism Campoeng, it requires the role of those involved to achieve what they aspire to. The role of the Government is very important in controlling the function of the region because it is a regulator in structuring buildings and a sustainable environment. Communities can provide several needs that can make building owners, workers and visitors feel comfortable in interacting in the region. One of the proposed programs can improve the quality of the environment and improve the image of the area based on the role of the Government and the community is the implementation of demarcation lines in the area of ceramic craftsmen; the opening of the space can be used as a transitional space between public territory and primary territory so that it will integrate visitor culture and ceramic craftsman culture. If everything can be realized, it is hoped that this region will have social values, scientific values and commercial values that benefit the community and the environment as well as be sustainable in realizing prosperity for its inhabitants.
\end{abstract}

Keywords : building arrangement, environment, sustainable.

\title{
1. PENDAHULUAN
}

Paguyuban Keramik Dinoyo, memiliki 31 anggota yang memiliki aktivitas menjual produk keramik dan memproduksi keramik. Saat ini, didapatkan 18 anggota yang masih aktif sebagai pedagang produk keramik berupa vas bunga, souvenir, guci serta lampu set; maupun 3 anggota yang aktif memproduksi keramik. Proses pembuatan keramik di kawasan Dinoyo, dimulai dari pengolahan bahan baku dari berbagai material, pembentukan, pengeringan, pengglasiran serta pembakaran (Adhi,2016); dari ketiga produsen keramik tersebut, hanya satu yang melakukan proses pengeringan dihalaman rumahnya sehingga dapat memperkuat citra kawasan pengrajin keramik.

PAWON: Jurnal Arsitektur, Nomor 02 Volume III, Juli-Desember 2019, ISSN 2597-7636 


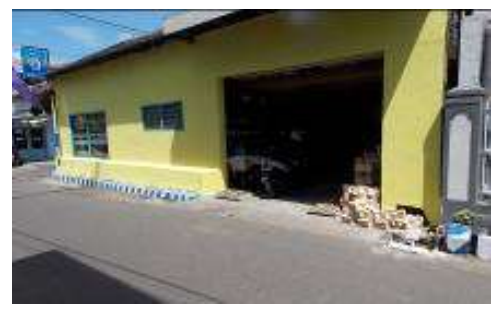

Gambar. 1

Pengrajin keramik yang melakukan proses pembuatan keramik dihalaman rumah Sumber: koleksi pribadi

Keberadaan ruang pamer sebagai media informasi untuk produk keramik bagi masyarakat yang terdapat di kawasan Dinoyo, merupakan alih fungsi ruang sehingga keberadaannya terlalu dipaksakan dan kurang sesuai dengan tuntutan perilaku penghuni, pekerja maupun pengunjung; apabila dilihat dari awal kegiatannya, pengadaan fasilitas ruang ini merupakan wadah kegiatan sampingan dengan modal yang terbatas. Tatanan bangunan antar ruang pamer dihubungkan dengan jalan umum yang sibuk dengan lalu-lintas kendaraan masyarakat dan merupakan satu-satunya fasilitas yang didapatkan pada kawasan pengrajin; di kawasan ini juga belum terjadi sinkronisasi fasilitas apabila dihubungkan dengan keberadaan fasilitas kota.

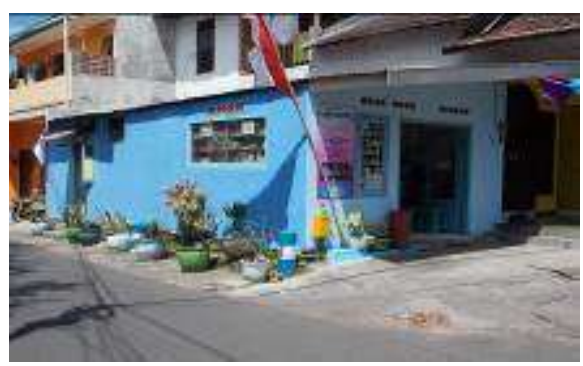

Gambar. 2

Ruang Pamer yang merupakan alih fungsi ruang Sumber: koleksi pribadi

Budaya pembuatan keramik, membutuhkan suatu karakteristik ruang untuk melakukan kegiatan yang memiliki derajat privasi, afiliasi dan kemungkinan pencapaian (Altman,1980), adapun kebutuhan ruang sesuai teritorinya diklasifikasikan dalam 3 golongan, yakni teritori primer, teritori sekunder, dan teritori publik. Teritori primer adalah tempat-tempat yang sangat pribadi sifatnya, hanya boleh dimasuki oleh orang-orang yang sudah sangat akrab atau yang sudah mendapat ijin khusus; teritori sekunder adalah tempat-tempat yang dimiliki bersama oleh sejumlah orang yang sudah cukup saling mengenal sedang teritori publik adalah tempat-tempat 
terbuka untuk umum yang pada prinsipnya setiap orang diperkenankan untuk berada di tempat tersebut.

Permasalahan arsitektur lingkungan dan perilaku, mengupayakan penyelesaiannya dengan memperhatikan psikologis manusia yang disebabkan karena aspek-aspek lingkungan dimana mereka beraktivitas (Stokols,1977), hal ini mengakibatkan karakteristik setting rumah tinggal di kawasan pengrajin berdasarkan fasilitas lingkungan binaan yang kurang sesuai dengan tuntutan perilaku (Haryadi,1989). Hal ini terlihat pada lingkungan mikro, yakni tata ruang pamer serta keberadaan fasilitas ruang transisi yang terbatas bagi pengunjung, pada lingkungan meso yakni ruang penghubung antar ruang pamer serta pada lingkungan makro yakni penghubung fasilitas kawasan dengan kota (Joyce,2004). Penataan bangunan dan lingkungan membutuhkan pengkajian makna kultural dengan tolok ukur estetika, peran sejarah serta pengaruh terhadap lingkungan (Sidharta,1989) maupun nilai-nilai sosial berdasarkan kualitas tempat atau lingkungan yang menjadi pusat kegiatan, nilai-nilai ilmiah yakni memperhatikan manfaat tempat atau lingkungan terhadap pengembangan ilmu maupun jasa informasi, serta nilai-nilai komersial yang memiliki arti penting terhadap suatu tempat atau lingkungan untuk kegiatan yang menghasilkan uang. Peran Pemerintah dalam mewujudkan pembangunan berkelanjutan (Keating,1994), yakni menekankan pentingnya programprogram pembangunan yang menggunakan bahan-bahan lokal, rancangan yang hemat energi, bahan-bahan yang tidak membahayakan kesehatan dan lingkungan, serta penggunaan teknologi padat karya yang mempekerjakan lebih banyak orang.

\section{TINJAUAN PUSTAKA}

Keberadaan suatu kawasan perlu diketahui potensi maupun permasalahan yang berasal dari lingkungan disekitarnya, adapun potensi tersebut dapat berupa kekuatan-kekuatan (strengths) serta kesempatankesempatan (opportunities), sedangkan permasalahan berupa kelemahankelemahan (weakness) maupun tekanan-tekanan (threats) dari luar kawasan (Indriyo,1987). Proses analisa SWOT dimaksudkan, untuk melakukan evaluasi purna huni kawasan pengrajin keramik guna mewujudkan suatu Kampoeng Wisata Keramik Dinoyo yang telah diwacanakan oleh para penghuni maupun pengrajin agar keberlanjutan Sentra Keramik Dinoyo tetap lestari.

Pada rancangan tatanan bangunan dan lingkungannya, perlu mengkaji beberapa hal diantaranya; keberadaan tata guna lahan, bentuk dan massa bangunan, sirkulasi dan parkir, ruang terbuka, ruang pejalan kaki, kegiatan penunjang, penanda lingkungan serta preservasi (Shirvani,1985). Agar tetap memberikan karakteristik suatu kawasan, maka konsep rancangan kawasan

PAWON: Jurnal Arsitektur, Nomor 02 Volume III, Juli-Desember 2019, ISSN 2597-7636 
keramik Dinoyo perlu memperhatikan aksesibilitas, kesesuaian dengan lingkungan, orientasi, identitas, ketertarikan serta kenyamanan ditinggali (Shirvani,1985).

\section{METODE PENELITIAN}

Melakukan pengumpulan data lapangan guna mendapatkan informasi tentang permasalahan untuk penataan bangunan dan lingkungan pada kawasan pengrajin keramik di Dinoyo, antara lain :

a. Kondisi eksisting yang memiliki keterbatasan pada pencapaian menuju pusat kegiatan yakni ruang pamer dan tempat produksi keramik, mengingat lebar badan jalan masuk kawasan selebar 5 meter akan menyempit menjadi 3 meter pada kawasan pertokoan yang menyediakan kebutuhan masyarakat yang berupa perlengkapan rumah tangga antara lain aneka vas dan guci hingga souvenir untuk pernikahan.

b. Keterbatasan fasilitas ruang transisi yang menampung pengunjung dari luar kawasan menuju tempat pedagang keramik, sehingga apabila pengunjung telah memasuki kawasan pengrajin dan akan berbelanja di toko keramik akan kurang mendapatkan fasilitas karena keterbatasan tempat parkir.

c. Kurangnya mendapatkan kesan sebagai kawasan pengrajin keramik, karena jarangnya pengrajin mengekspose kegiatan proses produksi kepada masyarakat disebabkan fasilitas lahan yang dimiliki oleh pengrajin terbatas.

Melakukan analisa guna pemecahan masalah pada kawasan dengan mengkaji beberapa hal, diantaranya :

a. Tata guna lahan, di kawasan pengrajin keramik Dinoyo sebagaian besar lahannya digunakan untuk permukiman berkepadatan tinggi dimana nilai penggunaan lahannya masih lebih rendah apabila dibandingkan dengan kawasan pusat kota.

b. Bentuk dan massa bangunan, memiliki orientasi pada Jalan M.T. Haryono gang 9 maupun pada Jalan M.T. Haryono gang 11.

c. Sirkulasi dan parkir, terjadi sirkulasi dua arah pada Jalan M.T. Haryono gang 9 karena lebar badan jalannya 5 meter hingga depan bekas Pabrik Keramik kemudian menyempit menjadi lebar badan jalan 3 meter saat berada di bagian arah barat bekas Pabrik Keramik dengan sirkulasi hanya kearah barat; sedangkan pada Jalan M.T. Haryono gang 11 dengan lebar badan jalan kurang dari 3 meter dengan sirkulasi dua arah. Parkir kendaraan roda dua bagi pengunjung ada pada enam ruang pamer, sedangkan roda empat maupun kendaraan penumpang ukuran besar pada halaman bekas Pabrik Keramik. 
d. Ruang terbuka, terdapat hanya pada pulau jalan serta lahan didepan bekas Pabrik Keramik yang merupakan aset properti Pabrik Keramik.

e. Ruang pejalan kaki, tidak didapatkan fasilitas tersebut; sehingga pengunjung yang berkunjung pada ruang pamer ataupun tempat produksi akan berjalan kaki menyusuri jalan yang ada dan menyatu dengan kendaraan yang melewatinya.

f. Kegiatan penunjang, yang sifatnya insidental apabila ada kunjungan pelajar, mahasiswa ingin belajar membuat keramik; penjelasan berupa teori praktis dilakukan di ruangan bekas Pabrik Keramik kemudian dilanjutkan praktek pada tempat produksi keramik.

g. Penanda lingkungan, keberadaan tengeran (landmark) ada pada bekas Pabrik Keramik Dinoyo, titik temu antar jalur (nodes) berada pada pulau jalan di depan bekas Pabrik Keramik, keberadaan jalur penghubung (paths) yang menghubungkan tempat parkir kendaraan roda empat atau lebih dengan tempat ruang pamer (showroom) maupun tempat produksi keramik yakni Jalan M.T. Haryono gang 9 dan Jalan M.T. Haryono gang 11 belum didapatkan fasilitas yang khusus untuk pengunjung yang berupa trotoar, batas wilayah (edges) yang membedakan antara wilayah perumahan warga dengan perumahan pengrajin berupa gapura di pertigaan Jalan M.T. Haryono dengan Jalan M.T. Haryono gang 9, kawasan (district) terdapatnya pengrajin keramik di sebagian besar perumahan sepanjang Jalan M.T. Haryono gang 9 dan sebagaian Jalan M.T. Haryono gang 11.

h. Preservasi, adalah pelestarian suatu tempat persis seperti keadaan aslinya tanpa ada perubahan, termasuk upaya mencegah penghancuran perumahan para pengrajin yang difungsikan sebagai tempat ruang pamer serta bekas Pabrik Keramik Dinoyo.

Penetapan konsep rancangan, dengan memperhatikan :

a. Kenyamanan aksesibilitas, yakni produk rancangan yang berupa fasilitas untuk mengakses suatu tempat atau kawasan bagi para pemilik, pekerja maupun pengunjung dalam melakukan aktivitasnya menuju maupun meninggalkan suatu tempat dalam kawasan pengrajin keramik seyogyanya ditata sedemikian rupa sehingga kesesakan maupun kepadatan dalam kawasan tidak terjadi.

b. Kesesuaian lingkungan, yakni memadukan aktivitas dari kegiatan yang spesifik dari suatu tempat atau kawasan pengrajin keramik maupun gips dengan fasilitas lain yang berupa tempat maupun lingkungan ataupun kawasan disebelahnya secara serasi sehingga dapat menghasilkan suasana interaksi yang nyaman dan menarik, baik bagi penghuni maupun pengunjung kawasan pengrajin. Pembukaan ruang terbuka baru, dengan tujuan untuk menambah pasokan udara bersih serta menambah luasan resapan air hujan diharapkan dapat meningkatkan kualitas lingkungan pada kawasan pengrajin keramik.

PAWON: Jurnal Arsitektur, Nomor 02 Volume III, Juli-Desember 2019, ISSN 2597-7636 
c. Orientasi, merupakan suatu arah hadap bagi bangunan yang berada pada kawasan pengrajin, hal tersebut dimaksudkan untuk memaknai karakteristik sesuai potensi dan permasalahan kawasan agar didapatkan produk rancangan yang spesifik sesuai keberadaan eksisting tapak, agar tampilan mudah dipahami oleh pengunjung maka karakteristik tempat usaha dengan bukaan lebar pada dinding depan perlu dilakukan.

d. Identitas, keberadaan suatu tapak secara geografis memiliki karakter sesuai budaya, potensi lingkungan kawasan serta menyelesaikan permasalahan suatu kawasan agar memiliki identitas sesuai sosial dan budaya, memenuhi azas manfaat serta memajukan ilmu pengetahuan bagi masyarakat yang berinteraksi dengan kawasan disini, adanya simbol guci dan warna kuning seyogyanya digunakan sebagai ornament pada bangunan sehingga mudah dipahami oleh pengunjung.

e. Ketertarikan, akan menjadi sesuatu yang saling membutuhkan diantara pengrajin dan pengunjung sehingga masing-masing pihak berusaha melakukan interaksi dimana pihak pengrajin menyediakan pilihan produk kerajinan yang menarik minat pengunjung demikian pula kawasannya menjadi sesuatu yang menarik karena menumbuhkan keakraban dalam berinteraksi; dapat diwujudkan dengan keberadaan ruang transisi pada lingkup kawasan maupun ruang pamer atau tempat produksi.

f. Kenyamanan, didapatkannya fasilitas sesuai tuntutan kegiatan baik suasana lingkungan maupun proses berinteraksi antara pengrajin, pemilik maupun pengunjung dapat melakukan aktivitasnya dengan bebas dan tanpa tekanan pengaruh fisik atau psikis dalam pemenuhan kebutuhannya; perwujudannya dengan menghadirkan teritori bagi pengunjung yang tidak tumpang tindih dengan fungsi yang lain.

Penerapan rancangan sesuai lingkungannya, yang meliputi :

a. Lingkungan mikro, yang terdiri dari tata ruang pada bangunan ruang pamer atau tempat produksi dengan ruang transisi sebagai penghubung teritori primer dengan teritori publik. Keberadaan ruang pada bangunan agar dapat berfungsi secara optimal, dibutuhkan pencahayaan yang berbeda untuk ruang pamer maupun tempat produksi keramik (Agnes,2014). Pada ruang pamer dapat dicapai dengan sistem pencahayaan setempat, hal ini akan menghasilkan tingkat pencahayaan yang tidak merata sehingga armatur (rumah lampu) ditempatkan di bagian-bagian tertentu dalam ruang yang membutuhkan cahaya lebih banyak. Tempat produksi keramik, perlu menerapkan sistem pencahayaan merata di seluruh ruangan dengan cara memasang armatur secara merata dengan membentuk pola teratur pada langitlangit. Selain pencahayaan, dibutuhkan pula ventilasi bangunan; yang berfungsi mengalirkan udara yang mudah menembus seluruh ruangan agar kelembaban tidak merusak pada bangunan; dibutuhkan bukaan 1/3 
dari luas lantai agar pergantian udara dapat terjadi dengan baik (Mangunwijaya, 1980).

b. Lingkungan meso, berupa ruang penghubung antar tempat ruang pamer maupun tempat produksi dengan ruang transisi kawasan sebagai bagian dari ruang inti dari suatu kawasan, diwujudkan pada teritori untuk pengunjung yang berupa trotoar sesuai potensi.

c. Lingkungan makro, sebagai penghubung antara ruang kawasan dengan ruang kota agar terjadi sinergitas rancangan yang baik antara kota dan kawasan dengan paduan yang harmoni, diwujudkan dengan ruang terbuka hijau yang difungsikan sebagai tempat parkir di depan bekas Pabrik Keramik.

\section{HASIL DAN PEMBAHASAN}

Penataan bangunan dan lingkungan adalah kegiatan pembangunan untuk merencanakan, melaksanakan, memperbaiki, mengembangkan atau melestarikan bangunan dan lingkungan/kawasan tertentu sesuai dengan prinsip pemanfaatan ruang dan pengendalian bangunan gedung dan lingkungan secara optimal, yang terdiri dari proses perencanaan teknis dan pelaksanaan konstruksi serta kegiatan pemanfaatan, pelestarian dan pembongkaran bangunan gedung dan lingkungan.

Perencanaan bangunan dan lingkungan suatu kawasan mengikutsertakan beberapa parameter, antara lain koefisien dasar bangunan, koefisien lantai bangunan, ketinggian bangunan, garis sempadan dan luas perpetakan tanah. Koefisien dasar bangunan pada dasarnya merupakan perbandingan antara luas dasar bangunan dengan luas lahan dimana bangunan tersebut berada. Penggunaan lahan dengan intensitas kegiatan tinggi tentunya akan memanfaatkan lahan seefisien mungkin sehingga nilai koefisien dasar bangunan menjadi tinggi pula, sebaliknya penggunaan lahan dengan intensitas kegiatan rendah akan memanfaatkan lahan dengan koefisien dasar bangunan yang rendah pula. Koefisien lantai bangunan pada dasarnya adalah perbandingan antara luas lantai bangunan secara keseluruhan dengan luas lahan dimana bangunan tersebut berada. Seperti halnya koefisien dasar bangunan, penetapan koefisien lantai bangunan ditetapkan berbeda antara tiap jenis peruntukan lahan. Penggunaan lahan dengan intensitas kegiatan tinggi tentunya akan memanfaatkan lahan seefisien mungkin sehingga nilai koefisien lantai bangunan menjadi tinggi pula, sebaliknya penggunaan lahan dengan intensitas kegiatan rendah akan memanfaatkan lahan dengan koefisien lantai bangunan yang rendah pula. Penetapan garis sempadan bangunan sesuai Permen PU nomor 29/PRT/2006 ditetapkan dalam rencana tata ruang, rencana tata bangunan dan lingkungan serta peraturan bangunan setempat didasarkan pada pertimbangan keamanan, kesehatan, kenyamanan dan keserasian dengan lingkungan serta ketinggian bangunan. Dalam pasal 13 undang-undang nomor 28 tahun 2002 juga menjelaskan

PAWON: Jurnal Arsitektur, Nomor 02 Volume III, Juli-Desember 2019, ISSN 2597-7636 
tentang garis sempadan bangunan atau GSB adalah sebuah garis yang menjadi batas jarak bebas minimum dari sisi paling luar sebuah massa bangunan terhadap batas lahan yang dikuasai; pengertian yang dapat ditarik dari hal ini adalah GSB merupakan batas bangunan yang diizinkan dalam pembangunan rumah maupun gedung. Faktor penentu garis sempadan bangunan adalah letak atau tempat dari lokasi berdirinya bangunan tersebut, untuk sebuah rumah yang berdiri dipinggir jalan, maka yang menentukan GSB-nya adalah fungsi dan kelas jalan, sementara bila bangunan terletak di lingkungan permukiman maka kisaran standarnya yakni sepanjang 3 hingga 5 meter. Luas petakan lahan yang dimaksudkan adalah lahan yang dikuasai pemilik/pengrajin untuk kegiatan usaha keramik maupun gips dengan luas mulai 40 hingga 321 meter persegi.

Pelaksanaan bangunan dan lingkungan pada kawasan pengrajin keramik Dinoyo disesuaikan dengan RDTRK kecamatan Lowokwaru yakni merupakan kawasan perumahan berkepadatan tinggi dan industri kecil diarahkan untuk memanfaatkan lahan dengan KDB 50 hingga 60\%, sedangkan kawasan perumahan kepadatan tinggi dan industri kecil diarahkan untuk memanfaatkan lahan dengan KLB 50 hingga 120\%. Ketinggian bangunan untuk kawasan pengrajin keramik, yang termasuk kawasan perumahan kepadatan tinggi dan industri kecil diarahkan dengan ketinggian bangunan antara 1 hingga 2 lantai.

Perbaikan bangunan dan lingkungan pada kawasan pengrajin, dikaitkan dengan keberadaan ruang penerima pada ruang pamer produk keramik yang dapat menjadikan pengunjung merasa nyaman dalam beradaptasi dari jalan menuju ruang pamer tersebut. Hal ini dapat berupa selasar bangunan dan kebanyakan difungsikan untuk parkir motor pengunjung; bagi ruang pamer keramik yang tidak menyediakan fasilitas parkir pengunjung akan menjadikan pengunjung kurang tertarik masuk kedalam ruang pamer karena akan memarkir motornya ditepi jalan dan hal tersebut akan mengganggu kelancaran lalu lintas pada kawasan tersebut. Sejalan dengan dicanangkannya sebutan Kampoeng Wisata Keramik oleh warga RW 03 pada kawasan pengrajin keramik; menjadikan bangunan mereka yang memiliki mata pencaharian sebagai pengrajin atau bukan diharapkan mematuhi peraturan tentang keberadaan garis sempadan bangunan, sehingga meletakkan bangunan dibelakang garis sempadan yang pada akhirnya dapat tercipta ruang transisi bagi pengunjung sehingga dapat menambah rasa nyaman apabila berkunjung pada ruang pamer keramik. Fasilitas ruang transisi sudah diberikan oleh sebagian kecil pemilik ruang pamer yang tergabung dalam Paguyuban Keramik Dinoyo, sehingga pengunjung merasa nyaman dalam menjalankan aktivitasnya untuk memenuhi kebutuhan akan produk kerajinan keramik.

Pengembangan/pelestarian bangunan dan lingkungan pada kawasan, perlu mempertimbangkan 3 hal guna pelestarian bangunan dan lingkungan kawasan pengrajin keramik, hal tersebut adalah pemenuhan nilai sosial, nilai 
ilmiah serta nilai komersial. Pemenuhan nilai sosial yakni keberadaan bangunan atau lingkungan yang menjadi pusat kegiatan kerajinan keramik sejak terpilinnya lokasi ini oleh Lembaga Penyelenggara Perusahaanperusahaan Industri yakni Perusahaan Daerah Keramika Yasa sebagai produsen peralatan makan dan minum seperti piring, cangkir, moci, basi dan peralatan lainnya. Saat ini, proses sosial masyarakat dalam pemenuhan kebutuhan keramik terjadi pada beberapa ruang pamer maupun tempat produksi sehingga aktivitasnya menyebar pada kawasan keramik Dinoyo. Pemenuhan nilai ilmiah, yakni keberadaan bangunan atau lingkungan yang memiliki manfaat terhadap pengembangan ilmu maupun jasa informasi; apabila dikaitkan dengan keberadaan tempat produksi keramik yang mengenalkan beberapa alternatif teknologi dalam proses pembuatan keramik; sehingga masyarakat dapat memilih yang paling sesuai bila akan memproduksi keramik sesuai tuntutan kebutuhan; demikian pula dalam pembuatan souvenir dari gips. Pemenuhan nilai komersial, yakni keberadaan bangunan atau lingkungan yang memiliki arti penting guna melakukan kegiatan yang menghasilkan uang; bila dikaitkan dengan keberadaan ruang pamer yang menampung produk keramik dari beberapa produsen, apabila pengunjung ingin mendapatkan produk tersebut maka dilakukanlah kegiatan transaksi yang menghasilkan uang.

Berdasarkan Peraturan Menteri Pekerjaan Umum nomor 06/PRT/M/2007 tentang Pedoman Umum Tata Bangunan Dan Lingkungan, maka penerapannya pada Kawasan Pengrajin Keramik di Dinoyo Malang digunakan sebagai panduan rancang bangun suatu lingkungan/kawasan guna mengendalikan pemanfaatan ruang, penataan bangunan dan lingkungan serta memuat materi pokok ketentuan program bangunan dan lingkungan, rencana umum dan panduan rancangan, rencana investasi, ketentuan pengendalian rencana dan pedoman pengendalian pelaksanaan pengembangan lingkungan/kawasan.

Program bangunan dan lingkungan, dilakukan dengan melakukan sosialisasi peraturan mengingat keberadaan bangunan yang sudah berdiri sebelum kegiatan kerajinan keramik ada; hal ini tentu masih sulit untuk mengakomodasi peraturan tentang tata banguan dan lingkungan, untuk bangunan yang baru didirikan tentunya dapat diberlakukan tentang advice planning dalam mendapatkan ljin Mendirikan Bangunan. Kondisi lingkungan permukiman yang padat menjadikan bidang resapan air hujan sangat terbatas, oleh karenanya dibutuhkan penyadaran yang berupa himbauan kepada para penghuni untuk menyesuaikan perletakan bangunan dibelakang GSB, agar terbentuk ruang terbuka yang dapat memberikan kesempatan tanaman tumbuh dan menghasilkan udara bersih sehingga meningkatkan kualitas lingkungan.

Rencana umum dan pelaksanaan pembangunan kawasan oleh masyarakat sudah terjadi jauh sebelum Panduan Rancangan, rencana umum untuk panduan rancangan pada kawasan pengrajin keramik di

PAWON: Jurnal Arsitektur, Nomor 02 Volume III, Juli-Desember 2019, ISSN 2597-7636 
Dinoyo, sudah tercantum pada Rencana Detail Tata Ruang kota Malang, yakni diberlakukannya KDB 50-60\%, KLB 50-12\%, TLB 1-2 lantai, Jarak bangunan ke bangunan di persil sebelahnya minimal 2 meter.

Rencana investasi, hal ini merupakan sesuatu yang tersulit didapatkan pada para pengrajin keramik di kawasan Dinoyo; yang terjadi di lapangan adalah sesuatu yang memprihatinkan karena dalam prinsip berdagang mereka, hanya mengandalkan penghasilan karena rejeki dari Yang Maha Pemurah tanpa mengalokasikan waktu sebagai variabel dalam business plan mereka.

Ketentuan pengendalian rencana, selama memenuhi advice planning dan memenuhi ketentuan persyaratan mendapatkan IMB sepertinya dapat mewakili ketentuan yang dapat menjamin keberlanjutan kawasan; apabila terlalu ketat dalam pemberlakuan peraturan, sepertinya hal tersebut tidak dapat direalisasikan pada kawasan pengrajin keramik Dinoyo, mengingat hal tersebut maka ketentuan yang ada juga diberlakukan oleh Pemerintah Daerah secara bijaksana dan pihak terkait memberlakukan dengan prinsip kompromi.

Pedoman pengendalian pelaksanaan, apabila sengaja melakukan hal yang merugikan bagi lingkungan yang tentunya juga merugikan bagi warga masyarakat di kawasan itu; maka petugas Pemerintah Daerah dalam hal ini SATPOL PP akan melakukan penertiban.

\section{KESIMPULAN}

Penerapan prinsip pembangunan yang taat azas terhadap diberlakukannya Garis Sempadan Bangunan, akan membentuk ruang terbuka hijau yang akan meningkatkan kualitas lingkungan sekaligus terbentuknya ruang transisi yang dapat difungsikan mengekspose proses pembuatan keramik untuk masyarakat sehingga Citra Kawasan akan meningkat. Pemberlakuan Garis Sempadan Bangunan untuk Jalan M.T. Haryono gang 9 selebar satu setengah meter dari pagar depan sebagai pembatas lahan yang dimilikinya, sedangkan Garis Sempadan Bangunan untuk Jalan M.T. Haryono gang 11 selebar satu meter tigapuluh sentimeter diukur dari batas lahan bagian depan yang berbatasan dengan daerah milik jalan.

Keberadaan trotoar pada sisi jalan, sebagai peningkatan layanan bagi pengunjung agar lebih nyaman berada pada kawasan pengrajin keramik karena merupakan fasilitas penghubung antar ruang transisi pada kawasan hingga dengan fasilitas kota; hanya dapat direncanakan sesuai potensi yang ada yakni selebar 60 sentimeter, hal tersebut berdasarkan hasil kajian Departemen Pekerjaan Umum tentang ruang yang dapat menampung gerak horisontal pada aktifitas manusia.

Mengusulkan alih fungsi bekas Pabrik keramik yang masih kokoh dan memiliki nilai kesejarahan menjadi Pusat Kegiatan Keramik yang dapat menampung kegiatan masyarakat dalam pendidikan, pelatihan, praktek pembuatan tentang keramik serta penjualan produk keramik. Selain itu, 
keberadaan tanah kosong yang menjadi aset Pabrik Keramik juga dialih fungsikan untuk tempat parkir pengunjung agar dapat menambah kemampuan tampung kendaraan pengunjung sehingga tidak mengganggu kelancaran sirkulasi pengguna jalan.

Penataan bangunan dan lingkungan pada kawasan pengrajin keramik di Dinoyo diharapkan dapat meningkatkan suasana yang lebih nyaman bagi pengunjung dan pengrajin keramik beserta pekerjanya untuk berinteraksi sekaligus meningkatkan kualitas lingkungan, adapun kendala bagi pemilik lahan yang luasannya terbatas menjadikan pengrajin ini kurang efektif dalam menjalankan aktivitasnya. Hal tersebut dapat, diselesaikan apabila alih fungsi Pabrik Keramik dijadikan fungsinya sebagai Pusat Kegiatan Keramik yang juga menampung aktivitas para pengrajin keramik dengan memprioritaskan mereka untuk beraktivitas pada pusat kegiatan keramik tersebut.

\section{DAFTAR PUSTAKA}

Adhi Widyarthara, 2016. Studi Lingkungan Perilaku pada Kawasan Pengrajin Keramik Guna Mencari Konsep Perancangan Arsitektur, di Kelurahan Dinoyo Kota Malang. Malang: Semnas SENIATI Februari 2017.

Agnes, 2014. Utilitas Bangunan. Yogyakarta: P.T. Bintang Pustaka Abadi.

Altman and Chemers, 1980. Culture and Environment Monterey. Ca: Brooks/Cole.

Haryadi, 1989. Residents Strategies For Coping with Environmental Press: Relations to House Settlements Systems in a Yogyakarta Kampung Indonesia PhD Dissertation. Milwaukee: University of Wincounsin at Milwaukee.

Joyce, Marcella Laurens, 2004. Arsitektur dan Perilaku Manusia. Jakarta: P.T. Grasindo.

Keating, 1994. Bumi Lestari Menuju Abad 21. Jakarta: Konphalindo.

Mangunwijaya, 1980. Pasal-Pasal Pengantar Fisika Bangunan. Jakarta: P.T. Gramedia.

Shirvani, 1985. The Urban Design Process. New York: Van Nostrand Reinhold Company.

Sidharta, Eko, 1989. Konservasi Lingkungan dan Bangunan Kuno Bersejarah Di Surakarta. Yogyakarta: Gajah Mada University Press.

Stokols, Daniel, 1977. Prespectives on Environment and Behavior: Theory, Research and Applications. New York: Plenum Press. 